
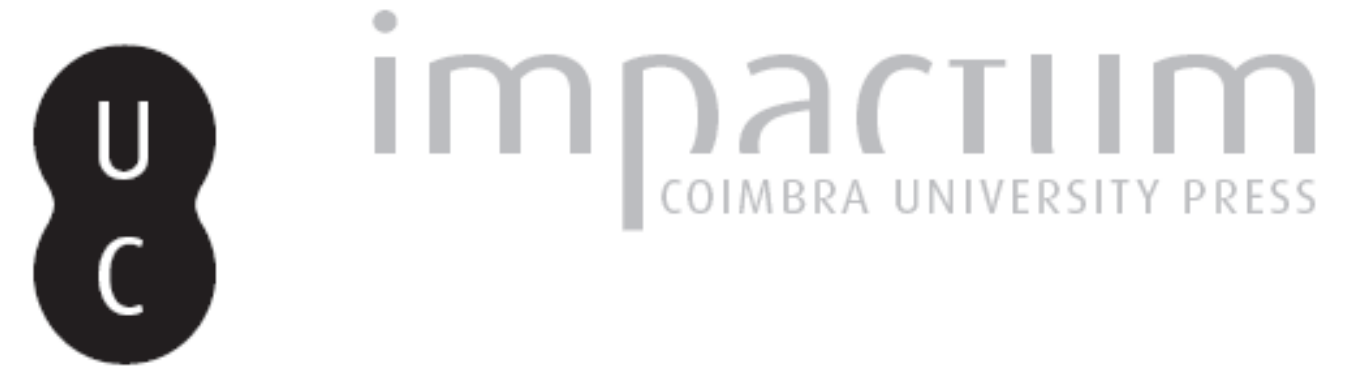

\title{
Antero: Poesia, alta voz dramática
}

\section{Autor(es): $\quad$ Pereira, José Carlos Seabra}

Publicado por: Imprensa da Universidade de Coimbra

URL persistente:

URI:http://hdl.handle.net/10316.2/43746

DOI:

DOI:https://doi.org/10.14195/2183-8925_13_9

Accessed : $\quad$ 26-Apr-2023 11:43:36

A navegação consulta e descarregamento dos títulos inseridos nas Bibliotecas Digitais UC Digitalis, UC Pombalina e UC Impactum, pressupõem a aceitação plena e sem reservas dos Termos e Condições de Uso destas Bibliotecas Digitais, disponíveis em https://digitalis.uc.pt/pt-pt/termos.

Conforme exposto nos referidos Termos e Condições de Uso, o descarregamento de títulos de acesso restrito requer uma licença válida de autorização devendo o utilizador aceder ao(s) documento(s) a partir de um endereço de IP da instituição detentora da supramencionada licença.

Ao utilizador é apenas permitido o descarregamento para uso pessoal, pelo que o emprego do(s) título(s) descarregado(s) para outro fim, designadamente comercial, carece de autorização do respetivo autor ou editor da obra.

Na medida em que todas as obras da UC Digitalis se encontram protegidas pelo Código do Direito de Autor e Direitos Conexos e demais legislação aplicável, toda a cópia, parcial ou total, deste documento, nos casos em que é legalmente admitida, deverá conter ou fazer-se acompanhar por este aviso.

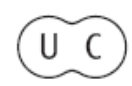


REVISTA DE HISTÓRIA DAS IDEIAS 13

\section{Antero de Quental}

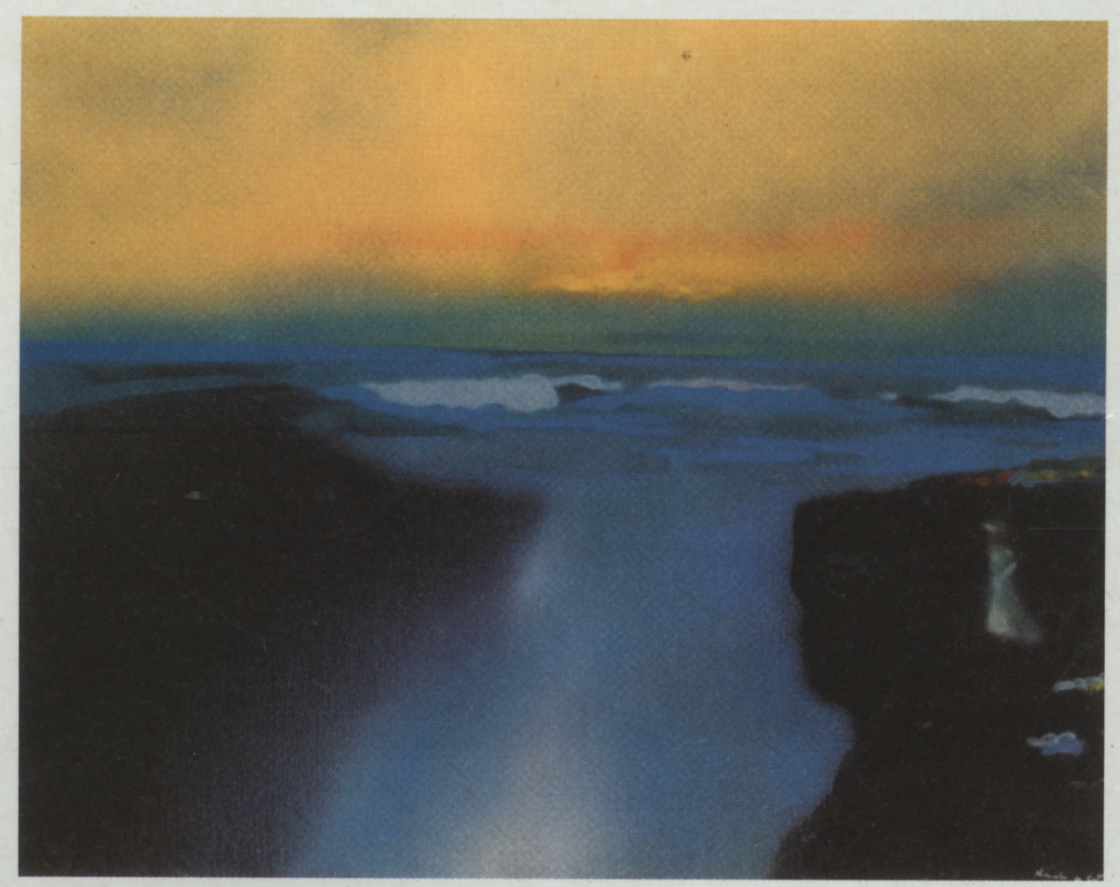

INSTITUTO DE HISTÓRIA E TEORIA DAS IDEIAS FACULDADE DE LETRAS

COIMBRA 1991 


\section{ANTERO - POESIA, ALTA VOZ DRAMÁTICA}

\section{Paixão da responsabilidade e questionação estética}

No trajecto existencial de Antero de Quental, nem a versatilidade da decisão, nem o oscilar entre acção e contemplação, nem mesmo o eventual deslizar da ataraxia para a apatia se confundem com consentimento da volubilidade ou abandono à frivolidade, porque sempre querem respeitar a livre gravidade do acto de viver. Nesse trajecto existencial, Antero de Quental cumpre-se, em inteireza de alma e com voz incoercível, pela paixão da responsabilidade. Ora, sendo mais ética e noética, essa paixão da responsabilidade passa também pela reflexão estética.

No fundamental pórtico da $2^{\mathrm{a}}$ edição das Odes Modernas, constituído pelo poema "Panteísmo" (de 1864) - que, com suas isotopias sémicas e fémicas $\left({ }^{1}\right)$, dá grandiloquente expressão lírica a uma mundividência esteada na emergência da Vida, na Força em Movimento, enfim na energia do Espírito objectivando-se dialecticamente nos horizontes do Infinito ou do Indefinido (como uma onda que, almejando ser "onda sem praias", se realiza pelo menos como "onda que vai e vem", mas

* Faculdade de Letras da Universidade de Coimbra.

(') Construídas nomeadamente em torno da sucessão de formas verbais como "alevanta", "alteia", etc., e da reiteração do latinismo semântico de "surge", "Surgir! Surgir!" (retomado, et pour cause, com a conotação evangélica, na epígrafe neotestamentária do soneto metaliterário "A um Poeta"), bem como em torno da recorrência de imagens marítimas. 
onda que "nunca pára") -, bem pode o poeta, enquanto voz profética da Evolução ascensional da Natureza e da História, exclamar magnanimamente: "Que mais importa a forma?". O certo é que, colocando-se o Sujeito fora de uma relação dominial com o Mundo objectivo, para assumir antes idêntico regime de pensamento e idêntico ritmo de sentir, esse Sujeito vem a reconhecer que enquanto Poeta já não usufrui da irrelevância da forma: ao passar da visão do Mundo como Poema vital - "Ó formas! vidas! misteriosa escrita / Do poema indecifrável que na Terra / Faz de sombras e luz a Alma infinita!" $\left({ }^{2}\right)$ - para a criação da Poesia como universo outro, embora de sentidos vitais, o problema da forma artística torna-se candente, no quadro de uma poética implícita e de uma poética explícita que esperam pela justificada análise exaustiva.

\section{Pendências entre forma e fundo, entre ideia e sentimento}

A maturação das concepções estético-literárias de Antero de Quental - decerto sinérgica, embora nem sempre isomorfa, na relação com o seu exercício da paixão da responsabilidade-tem um marco primordial no prefácio à $1^{a}$ edição dos Sonetos (Coimbra, Dezembro de 1861).

Partindo da convicção (cuja formulação não parece conter a ambiguidade ulterior do procedimento) da indissociabilidade, aliás evolutiva, de forma e conteúdo da Arte $\left(^{3}\right)$, o texto "A João de Deus" que precede essa edição Sténio dos Sonetos de Antero parece destinar-se a defender a tese de que "A forma completa do lirismo puro é o Soneto" ( $\left.{ }^{4}\right)$. Porém, sob o signo do primado ontognoseológico e da precedência criativa do Sentimento (em disputa com as complexas e profusas inteligência e fantasia) $\left(^{5}\right)$, a discussão da configuração evolutiva da forma suscita logo duas linhas problemáticas: por um lado, a estimativa da mediação racional no processo de expressão do

(2) Antero de Quental, Odes Modernas, Segunda Edição, Porto/Braga, Livraria Internacional (Chardron), 1875, pp. 5, 6, 3, 5.

$\left({ }^{3}\right)$ "há para cada evolução da Arte uma forma própria, única, perfeita" (Antero de Quental, Sonetos de Antero, Coimbra, Editor - Sténio, 1861, p. V).

$\left.{ }^{4}\right)$ Idem, ibidem, p. V.

(5) "o sentimento é um - simples - porque é a parte eterna, imutável, divina do homem; o olho com que vemos a Deus, a mão com que lhe palpamos o seio" (idem, ibidem, p. VI). 
sentimento, mesmo no "lirismo puro da alma" (6); por outro lado, e ao arrepio do que será afinal a vocação do soneto na obra anteriana da maturidade, a coloção desse mesmo soneto fora da área das formas poéticas que, como a ode, correspondendo à inteligência e à fantasia, traduziriam "o mutável, o progressivo, a porta por onde nos entra o mundo, o pulmão com que aspiramos e respiramos o universo, o imenso" ()).

A insuficiência, por então, da aclimatação do Gemüt $\left({ }^{8}\right)$ axial no Romantismo originário - equivalente à redução teórica, entre Camilo e João de Deus, da doutrina oriunda de Vico $\left({ }^{9}\right)$ - e o desconhecimento, por então, das potencialidades que à imaginação criadora atribuía $o$ mais profundo e genuíno Romantismo europeu, bem como da síntese baudelairiana entre o inspirado e o artífico, não permitem, ainda, que vá longe a formulação dialéctica das relações fundo/forma, nem evitam o ressentimento de uma perda incoercível no trânsito ideativo desde o sentimento criador até à tradução formal. Pelo contrário, deixam enlear o jovem Antero numa fundamentação confessional do lírico e numa concepção tendencialmente expressivista desse lírico pendor que cumpre doravante ter presente, porque o seu rasto nunca será de todo eliminado e porque a sua insatisfatória pervivência, mesmo quando subreptícia, se revelará dialecticamente pregnante, ao potenciar novas respostas gerativas e discursivas.

De facto, o prefácio "A João de Deus", depois de glosar a primordialidade do "Sentimento" (assim mesmo já maiusculado), tenta deslindar o processo mediante o qual "o homem começa a ter consciência do sentimento" e a inteligência forceja por " penetrarn' alma", conduzindo a "Primeira transformação (...) do sentimento", em que "A inteligência forma ideia do sentimento". Mas, quando julgamos de todo positiva a perspectivação desse processo, eis que a sua prossecução em busca da forma própria se recobre de reservas instigadas ora pela conotação

${ }^{6}$ ) Pois diz-se: "o soneto, o lirismo puro da alma, a ideia que traduz o eterno sentimento"; e, logo depois, a afirmação inicial tem outro paralelo em "há uma forma para cada ideia" (idem, ibidem, p. VI).

$\left(^{7}\right)$ Idem, ibidem, p. VI.

${ }^{(8)}$ Veja-se, em especial, Georges Gusdorf, L'Homme Romantique, Paris, Payot, 1984, Parte I, Cap. VI ("Gemüt, Stimmung, Harmonies"), pp. 88-126.

( $)$ Cf. citação e comentário por Óscar Lopes, em "O Antinaturalismo de Antero", in Boletim - Universidade do Porto, Ano II, N. 12 (Fevereiro de 1992), pp. 31-32. 
pejorativa, ora pela asserção lamentosa, que acompanham o reconhecimento da urgência comunicativa e da concretização textual: "Desde que se apossou dele a inteligência, não parece o mesmo: assaltam-noestranhas veleidades, caprichos desconhecidos.", "Quanto perdeu ele já com passar de sentimento ao estado d'ideia! Quanto não perderá agora passando d'ideia a facto!", "Aí temos pois o sentimento reduzido a ideia, à procura de forma.".

O êxito, portanto, de tal processo não pode evitar, no quadro da poética romântica, a noção de perda ínsita na combinação de "o claro, o preciso, o definido" (a que é feito equivaler a inteligência) com "o misterioso, o escuro, o vago" (a que é feito equivaler o sentimento). Permite, contudo, que o soneto se guinde a "forma superior do lirismo do coração", no quadro daquela mesma poética romântica, segundo a qual os grandes poetas podiam criar grandes sonetos mesmo quando "cansados, talvez exaustos d'imaginação e de ideia, sentiam, todavia, transbordar-lhe o coração".

Tais concepções arrastam elucidativa oposição entre "o Poeta" (que se ama, até às lágrimas) e "o Artista" (que se admira com arrebatamento), como se infere do louvor do soneto no interior da obra de Dante, de Miguel Ângelo, de Shakespeare e de Camões, em contraste com outras construções artísticas $\left({ }^{10}\right)$.

Curiosamente, as tendências e as dificuldades da problematização estética deste jovem Antero acabavam em "A João de Deus" - e já sob as engodosas aparências de se cingir às questões mais restritamente literárias - por ver-se associadas ao anúncio das dissençõese contendas da Questão Coimbrã.É que, delineando-se a genealogia do resgatado soneto - Camões, Bocage, João de Deus -, ali se pergunta retoricamente quem podia, entre os coetâneos, proceder à restituição daquela forma superior do lirismo - inexequível sem o selo da autenticidade na expressão pura da vivência mais profunda do sujeito -, para se responder com esta exclusão tipificante: "Certo que não seriam os Castilhos, nem os Lemos, nem..." $\left.{ }^{11}\right)$.

$\left({ }^{10}\right)$ Antero de Quental, loc. cit., pp. VII-IX e X-XI.

(11) Idem, ibidem, p. XII. 
3. Contra a trivialidade instrumentalizada e o aviltamento institucional de literatura "ultra-romântica"

O que se entrevê aqui - e também noutras Prosas da Época de Coimbra onde identicamente vão de par evolução da poética de Antero e antecipação das diatribes de ' 65 na convergente derrogação e denúncia da "trivialidade" $\left({ }^{12}\right)$ - é que o desenvolvimento das concepções anterianas sobre a natureza da Poesia e da produção textual se vai sujeitar ao ritmo exógeno e às injunções de um debate mais amplo, onde aliás aparecerão sobrepujadas pela postulação da condição do Poeta e das funções dos textos literários.

De facto, o que está por detrás daquela desvalorização dos Castilhos e dos Lemos é já o que justificará a "grande distância" a que, por 1867 , se situará do "romantismo inútil", enquanto contemporâneo "de Byron e de A. Comte" (conforme declara em carta a António de Azevedo Castelo Branco) $\left({ }^{13}\right)$.

Quando à exigência de autenticidade expressivo-vivencial se juntar a exigência de pregnante equação com os problemas e as ideias da época decorrente e da sociedade envolvente, despoletar-se-á o conflito entre as potencialidades de um Romantismo simultaneamente refontalizado e evoluído e, de outra banda, a degradação caseira desse Romantismo (na poética redutora, na textualidade medíocre, nos aviltantes mecanismos do funcionamento institucional da "literatura oficial").

Em Antero vai, com efeito, crescer a percepção de que, depois da penetrante e complexiva compreensão do Romantismo originário em Garrette Herculano, grassara em Portugal uma outra literatura romântica, que interpretava desfocadamente e degenerava aquele Romantismo originário - não só propagando uma amputação egotista, sentimentalista, verbalista e evasi va da aventura do Eu Absoluto, do donjuanismo fáustico, do titanismo, do historicismo centrado no Volksgeist, mas

( $\left.{ }^{12}\right)$ Veja-se, por exemplo, a "Carta de Henri Heine a Gérard de Nerval" (1864), a "Introdução" aos Cantos na Solidão de Manuel Ferreira da Portela (1865), e o ensaio incompleto "Arte e Verdade" (1865) nas Prosas da Época de Coimbra, Lisboa, Sá da Costa, 1973 (Ed. Crítica por A. Salgado Júnior), pp. 153 ss., 227 ss., 232 ss.

$\left({ }^{13}\right)$ Cf. Antero de Quental, Obras Completas - Cartas, Lisboa, Universidade dos Açores/Editorial Comunicação, 1989, vol. I, p. 92. 
também alienando o impulso prospectivo da Sehnsucht e desactivando os vectores "realísticos" do discurso profético. Agudizada pelos apelos das circunstâncias nacionais de ordem política e sócio-económica, bem como pela evolução ideológica de Antero, essa percepção motivará o antagonismo e a intervenção - que em nada se deixarão matizar pela evolução de Tomás Ribeiro e de outros em prol de uma estética romântica da naturalidade e da actualidade (e da sua pretensa realização lírica, narrativa e dramática) $\left({ }^{14}\right)$.

Quando Eça vier declarar que o cerne da Questão Coimbrã residira para Antero numa reivindicação ética $\left({ }^{15}\right)$ estará, sem dúvida, a acertar, embora tenhamos de modular a insurgência do paladino da liberdade intelectual e artística em termos, também, de conflito intergeracional e intrageracional em torno dos bens simbólicos e em termos de disputa pelo poder no campo cultural que é a literatura, com adopção de estratégia diferenciadora no interior da instituição literária. Assim, é de aceitar que Antero se insurge sobretudo contra um duplo processo de instrumentalização, de trivialização e de aviltamento da literatura - protestando perante o facto de a literatura dita "ultra-romântica" se haver tornado, por um lado, peça de convívio convencional e de entretenimento frívolo para a sociedade burguesa, e, por outro lado, meio de evidenciação de jovens bacharéis em busca da notoriedade social e da promoção na carreira administrativo-política; e consequentemente se insurge Antero contra a táctica de subordinação epigonal que esses noveis escritores adoptavam, ou a que se submetiam, para penetrarem no campo literário e para nele progredirem do apagamento da periferia para a hegemonia do centro.

Todavia, não podemos obliterar que para Antero de Quental estava também em causa - na Questão Coimbrã, nos seus pródromos e nas suas sequelas - o litígio entre duas concepções e concretizações da literatura (antecipadamente invertendo, ou tornando reversível, o

(14) Vide José Carlos Seabra Pereira, Tomás Ribeiro. Raizes e caminhos dum poeta romântico e liberal, Viseu, 1982, Separata de Beira Alta, vol. XLI, p. 841 ss., e Cesário Verde, um Realismo insatisfeito, A veiro, 1988, Separata da Revista da Universidade de Aveiro/Letras, n.. 4-5, pp. 250-255.

(15) Eça de Queirós, "Ulm génio que era um santo", in Notas Contemporâneas, Lisboa, Ed. Livros do Brasil, s.d., pp. 259-260 (primeiramente publicado em Antero de Quental-In Memoriam, Porto, Mathieu Lugan, Editor, 1896). 
alcance da invectiva de Teofilo, que, ao derivar o substantivo "Ultra-Romantismo", al veja um dessoramento sentimental-passadista que, a seus olhos, da literatura se estendera ao comportamento social). $\mathrm{Na}$ verdade, Antero denuncia a vacuidade escapista e artificiosa da temática afectiva e histórica, o derrame afectado da poesia de confidência ou de circunstância mundana, a extrapolação mecânica da vertente depressiva do mal du siècle (tédio, melancolia, fragilidade anímica, desalento fatalista), a estereotipização das imagens, do verso, da linguagem. Contra esta banalização e esta inocuidade da literatura vigente (que era a "literatura oficial" também denunciada na perspectiva ética e institucional) propugnava Antero uma literatura nova, mobilizadora e emancipadora pelo compromisso com uma visão "progressista" da Vida e da História, movida pelo desejo de apropriação da realidade envolvente e dirigida à acção transformadora dessa mesma realidade.

\section{Potencialidades do Romantismo e dissídios da Modernidade}

Três aspectos importa, entretanto, reter na participação de Antero na Questão Coimbrã e na interventiva evolução do seu posicionamento estético-literário.

Por um lado, libelo e proposta alternativa continuam a consumar-se, ambos, no interior do Romantismo. Assim sendo, a poética e a poesia de Antero vão doravante ter de cumprir-se na vigilante auto-regulação e auto-rectificação da imprescindível condição romântica. Nomeadamente, permanecerão poética e poesia da experiência transbordante, da vocação expansiva, da convicção irradiante e, por tudo isto, por sobre tudo isto, da voz ressonante. Ora, essa voz ressonante impor-se-á a si mesma expurgar a mera reiteração ou acumulação dos pequenos processos de ênfase em favor de uma ênfase dignificada, desde logo, na nobreza profética e, depois, na contenção do soneto-em ambos os casos, ênfase convivente, se não coincidente, com uma dramacidade multímoda, favorecida por outros vectores da condição estético-ideológica de Antero de Quental.

Por outro lado, o libelo e a proposta alternativa de Antero, nos opúsculos da Questão Coimbrã ou correlatos, relevam de uma concepção "conteudística" da literatura (ou, sob outra perspectiva, traem uma insanável dificuldade em renovar uma concepção orgânicae automórfica da obra literária, em que forma e conteúdo surgissem como 
gerativamente coincidentes). Assimé quando denunciam, como depois a sátira ficcional de Eça, o efeito deletério da literatura subromântica na sociedade portuguesa, quando corresponsabilizam essa literatura subromântica na decadência nacional e na alienação generalizada, quando cometem à nova literatura a missão de resgatar aquela decadência e de promover a emancipação humana (no quadro da Justiça e da Evolução ascensional). A Poesia renova-se então, mas apenas como a mais eficaz forma das ideias e como a mais alta voz da Consciência esclarecida, actual e actuante-em voluntarioso contraste com essoutra poesia de Castilho, paradigmática à rebours, onde no entanto repetidamente Antero continua a louvar a "beleza", a "perfeição da forma"!... $\left({ }^{16}\right)$.

Finalmente, as posições que, nos recontros e na sequência da Questão Coimbrã, Antero de Quental assume, integram-se numa sua ofensiva mental que consubstancia, sem dúvida, uma inédita investida contra a cultura tradicional e um decidido projecto de ruptura. Não sofre também dúvida que essa investida e esse projecto se traduzem numa dinâmica de racionalidade praxeológica (capaz de integrar superadoramente conclusões do Positivismo e capaz de construir uma metafísica indutiva sobre a validade do "naturalismo" no plano fenoménico), numa consagração do princípio da imanência, num relançamento ético do criticismo. Por tudo isso, aquela acção sócio-cultural integra-se num afrontamento em que Antero se move (e mobiliza a sua geração, para com ela deslocar Portugal) para uma modernidade de indesfarçável matriz iluminista. Mas há que situar as posições estético-literárias de Antero e, em particular, a sua condição poética no fio da navalha de uma dissociação no conceito de modernidade-assumindo aprofundadamente o que Eduardo Lourenço mitigadamente já reconheceu, quando reclamou: "o seu combate espiritual constitui um acontecimento sem precedentes na nossa Cultura. A bem dizer, o início da Modernidade entre nós, se admitirmos que essa Modernidade se acompanha de uma tomada de consciência histórica de carácter trágico. Sobre todos os planos, salvo o da escrita poética $\left({ }^{17}\right)$, a aventura

$\left({ }^{16}\right)$ Lembre-se a corroboração desse leit-motiv na "Nota" apendicular ao folheto $A$ Dignidade das Letras e as Literaturas Oficiais (cf. Prosas da Época de Coimbra, p. 316 ss.).

$\left.{ }^{17}\right)$ Sublinhado meu: trata-se, justamente, da linha fundamental de confronto no litígio das Modernidades. 
intelectual de Antero instaura entre nós uma experiência de ruptura cultural, (...)" $\left({ }^{18}\right)$.

É que, se confrontamos a obra global de Antero com as componentes do "projecto inacabado" da Modernidade $\left({ }^{19}\right)$, não custa reconhecer no autor um apologista do espírito da modernidade científico-sociológica, ao passo que só deparamos com parcial invasão do universo semântico-pragmático da obra literária por macrossignos (temas, motivos, personagens, etc.) provindos das manifestações daquela modernidade na civilização urbana e industrial distintiva da segunda metade de Oitocentos; e, sobretudo, só descobrimos na obra poética de Antero uma retraída actualização das componentes que ela partilha com a modernidade estética pós-baudelairiana e um quase constante distanciamento das componentes específicas dessa modernidade estética.

Com efeito, Antero quer-se operante já no interior da foucaultiana "idade da História", mas dá limitada prossecução, no plano artístico, aos vectores de processo insustível de incompletude, de baudelairiana prospeç̧ão do belo (eterno) na experiência mesma do transitório e de correlata conversão da linguagem, até aí tida por transparente e instrumental, em "objecto espesso e enigmático", aberta "ao devir e à flutuação dos sentidos" $\left({ }^{20}\right)$. Paralelamente, Antero participa, com o seu idealismo imanentista e objectivo $\left({ }^{21}\right)$, da era da subjectividade postulada, em suas potencialidades infinitas, como fonte do conhecimento e origem da criação, mas está ainda por discernir até que ponto deu prossecução ao regime irónico dessa primazia do eu (e do Eu Absoluto). É seguro, todavia, que esse processo se reveste em Antero apenas virtualmente de "inesgotável mobilidade, possibilidade de autoludíbrio, aguda consciência das contradições"; é seguro que,

( $\left.{ }^{18}\right)$ Eduardo Lourenço, "Antero ou o socialismo como utopia", in Poesia e Metafísica, Lisboa, Sá da Costa, 1983, p. 149.

$\left({ }^{19}\right)$ Retomamos a expressão consagrada por famosa conferência de Habermas em 1980 (cf. versão em espanhol, in Hal Forster, J. Habermas, J. Baudrillard y otros..., La Posmodernidade, Barcelona, Editorial Kairós, 1985, pp. 19-36). Vide também Jürgen Habermas, O Discurso Filosófico da Modernidade, Lisboa, Dom Quixote, 1990, e Antoine Compagnon, Les cinq paradoxes de la modernité, Paris, Seuil, 1990.

$\left({ }^{20}\right)$ Veja-se F. J. Vieira Pimentel, Literatura Portuguesa e Modernidade, Ponta Delgada, 1991, pp. 33-34.

(21) Veja-se Fernando Catroga, "A ideia de evolução em Antero de Quental", Biblos, vol. LXV, 1980, p. 383, e Joaquim de Carvalho, "Evolução Espiritual de Antero", in Obra Completa, Lisboa, Gulbenkian, vol. III, 1983, pp. 622, 680-681-682. 
nesse processo, Antero se temeu de abandonar-se à aventura que havia de conduzir a poética do fingimento e ao descentramento do eu protagonista da História e da linguagem, e ficou mesmo aquém de assumir que a linguagem fora "retirada da dependência das coisas e resolutamente atraída a incessante actividade do sujeito" ${ }^{22}$ ). Além disso, e sobretudo, Antero não quis - nem lhe pareceria viável, ou digno, no quadro da sua própria missão de paladino da modernidade sócio-ideológica - incorporar-se em pleno na "tradição do novo" e comprometer-se com a autarcia do estético que são peculiares da modernidade artística (com a autonomia dos valores estéticos e o autotelismo da criação artística, com a negati vidade a desdobrar-se em soberania da linguagem, com o discurso literário a distinguir-se barthesianamente pelo tropismo auto-reflexivo, metaliterário, e a reger-se por uma exigência endógena do novo, por uma insustível e obsessiva necessidade de contínua autoquestionação, autodesactualização, auto-refundação).

\section{A plataforma moderna da dramatização da Poesia}

Porém, apesar de tudo isto, o "calvário" da modernidade artística e a deriva estético-literária e poética de Antero de Quental têm de comum defluirem das potencialidades proteicas e dialécticas do Romantismo $\left({ }^{23}\right)$; e os seus distintos processos de actualização interseccionam-se por vezes, de modo hesitante mas fecundo. Da parte de Antero, essas aproximações encontram a sua plataforma de sustentação num ensaio de dramatização da lírica que, a dada altura do seu trajecto, Antero entrevê por motivações várias, e passa a almejar para a sua própria obra poética, e passa a propugnar para a poesia alheia. Essa dramatização, assim considerada como pertinente e até imprescindível para um adequado progresso da poesia no mundo moderno, está para além das dramaticidades expressiva e técnico-

${ }^{(22}$ Cf. F. J. Vieira Pimentel, ob. cit., pp. 36-37.

$\left({ }^{23}\right)$ Para o que aqui mais importa, convém lembrar, com Maria de Lurdes Ferraz (A Ironia Romântica, Lisboa, I.N.C.M., 1987, p. 36 ss.), que o Romantismo surge "caracterizado genericamente por antinomias profundas que se centram em torno da mais absoluta: do desejo ilimitado de a literatura, sendo a expressão do eu, único, ser também manifestação de infinito, sentimento", "é a ruptura consigo próprio, com a sua própria criação - ironia romântica -, a absoluta das antinomias". 
compositiva, da ênfase tensional e da encenação teatral, respondendo ao invés a um imperativo de superação transcendental da vivência egótica e de estranhamento objectivante da enunciação.

Correspondendo a uma discontínua problematização estético-literária, que por vezes retoma dificuldades teóricas que inicialmente foram apontadas, a lírica de Antero de Quental não se limitará a tentar substituir a juvenil pecha parenética $\left({ }^{24}\right)$ pela contenção dramática, quando dá alta voz poética aos ditames irrecusáveis da teleonomia profética, da lição dos sinais dos tempos e do combate aos obstáculos e forças adversas na missão emancipalista e galvanizante; nem se limitará a tentar preterir o desdobramento alegórico em favor do conflito dramático, quando dáalta voz poética à dialéctica idealista, e proudhonianamente serial, da Evolução ascensional enquanto lei inderrogável da Natureza, da História, do Espírito humano. Para além disso, a lírica de Antero conhecerá, então, um mais surpreendente e pregnante vector de dramatização - vector oriundo da reformulação do conceito de sinceridade poética, vector tributário do desajuste entre eventuais reconhecimentos de que "no nosso século a poesia tem raízes mais fundas do lado da inteligência do que do lado do coração" e as recorrentes afirmaçỗes da primazia do Sentimento $\left({ }^{25}\right)$, vector confortado pela vontade e capacidade de autopastiche (por sobre lapsos de tempo que implicavam solução de continuidade nos interesses, nos valores e nos modelos), e vector consumado enfim na configuração da instância poética como subjectividade não-individual ou como modalidade histórica da Consciência humana.

\section{Expressivismo egótico e objectivação da sinceridade artística}

A mesma retumbante "Nota" aposta por Antero à la edição das Odes Modernas, que postula como "mais poética" a voz que for "a mais alta" enquanto revolucionária adesão "ao sentir mais profundo do seu tempo", também postula que "a Poesia é a confīssão sincera do pensamento

${ }^{(24)}$ Cf. Joaquim de Carvalho, "Evolução Espiritual de Antero", loc. cit., pp. 565 e 566; idem, "Prefácio da Segunda Edição de Raios de Extinta Luz", in Obra Completa, vol. V, p. 59.

(25) Mas, por isso mesmo, em poemas anterianos como em muitos textos românticos, prevalece o "prazer da aliança entre ironia e sentimento"; e neles "Institui-se uma estratégia dramática" (cf. Maria de Lurdes Ferraz, ob. cit., p. 37). 
mais íntimo de uma idade" $\left({ }^{26}\right)$ - abrindo, através do desconcertante recurso aos lexemas "confissão" e "sincera", uma via de reequacionamento da noção de sinceridade poética ao arrepio precisamente do expressivismo confessional de matriz mussetiana $\left({ }^{27}\right)$ e de lamentável prole subromântica. Este pregnante rasgo de 1865 - obviamente favorável a uma dramatização do texto lírico, mas também obviamente coacto em qualquer poética que não aposte num moderno fortalecimento da mediação inteligente, da vigilância crítica, da consciência artífica - ver-se-á reforçado e modulado, embora de modo discontínuo e indeciso, por congeminações ulteriores; é o caso, por exemplo, de certa carta de 1874 a Oliveira Martins sobre o AnthéChrist de E. Renan, em que Antero pondera: "achoque o Renan apoia demais nos incidentes biográficos de meia dúzia de personagens e deixa na sombra o que é muito mais importante, o estado da consciência humana na época dos Césares" $\left({ }^{28}\right)$; e, complementarmente, é o caso das cartas, adiante referidas, que no fundo mais íntimo do eu vêem prevalecer a manifestação do "espírito humano" $\left({ }^{29}\right)$.

Em contrapartida, outros textos de Antero, porventura mais numerosos, parecerão reverter ao sincerismo egótico - como certa carta de 1876 a Lobo de Moura sobre o soneto "Transcendentalismo": "verdade pessoal, expressão exacta do meu íntimo sentir.(...) Posso chamar-lhe um salmo, uma efusão religiosa, porque está ali com efeito a minha religião, o meu culto da existência supra-sensível $(. .) ".\left({ }^{30}\right)$ - e parecerão retroceder para concessões à poética expressivista, à mimese de vivências pessoais, ao instintivismo criativo,

$\left({ }^{26}\right)$ Antero de Quental, Odes Modernas, Coimbra, Imprensa da Universidade, 1965, pp. 151 e 160.

${ }^{(27)}$ Não coextensivo à poética schlegeliana da expressão - "O íntimo é pressionado para fora como por uma força alheia a nós" - imarcescível na tradição romântica, mas a propósito da qual Maria de Lurdes Ferraz pode comentar: "Ora, a consciência dessa força é já uma porta aberta ao outro (eu). (...). É irónico, dramaticamente irónico, que no momento em que os românticos defendem a solitude do dizer estejam a instituir a necessária comunicação do seu acto de se afirmarem em solilóquio" (ob. cit., p. 37).

$\left({ }^{28}\right)$ Antero de Quental, Cartas, vol. I, p. 243.

$\left({ }^{29}\right)$ Cf., infra, notas $\left({ }^{86}\right)$ e $\left({ }^{87}\right)$.

$\left({ }^{30}\right)$ Antero de Quental, Cartas, vol. I, p. 352. Entretanto, convém não esquecer, na melhor tradição romântica a literatura irónica, enquanto meio que o e u usa para se auto-representar artisticamente, movimento dialéctico entre realidade e ficção, traduzia a duplicidade, o distanciamento, em súbitas mudanças de tom e de situação, ao mesmo tempo que se apresentava verídico, único, a própria vida (Maria de Lurdes Ferraz, $a b$. cit., p. 43). 
à naturalidade elementar de comunicação - como certa carta de 1889 a Queirós Ribeiro: "Vibra nos seus versos uma nota sã, de delicada e natural sensibilidade, de sincera comoção, que bastaria, a meu ver, para dar ao seu livro um lugar distinto (...) $\mathrm{Na}$ Vida, o sistema e o propósito valem mais que tudo: mas na Arte é só a espontaneidade, a vocação e o natural pendor que devemos seguir" $\left.{ }^{31}\right)$.

Neste trajecto sinuoso ou bifurcado através do espaço de potencialidades do Romantismo, vai-se jogar a sorte incerta da desmultiplicação discursiva. Vai jogar-se ainda sem o descentramento orfaico do eu, pois mesmo quando alguns sonetos (v.g. "No turbilhão", "Visão") colocam o sujeito à beira da dissolução da personalidade teimam em proceder ainda à reabsorção dos "fantasmas de mim mesmo" na soberania unitária do eu. Todavia, a sorte incerta daquela desmultiplicação discursiva vai jogar-se já na tendencial substituição da juvenil bipolaridade "Poeta" versus "Artista" pela pós-baudelaireana e pós-heineana bipolaridade homem/pensador versus poeta-artista.

\section{Ironia romântica e desdobramento objectivante}

Tal alteração torna-se exequível graças a um processo de dialectização subtil que leva a poesia de Antero de Quental desde o hirto humor que Joaquim de Carvalho concede a composições de Raios de extinta luz (v.g. "Fiat lux" de 1863) até ao complexo "humor transcendente" que Oliveira Martins louva nas composições derradeiras do poeta $\left({ }^{32}\right)$.

É um processo que abre o pensamento filosófico e a especulação estética de Antero à especificidade da ironia romântica. Por 1865, ano em que consonantemente explica o que entende por humorismo $\left.{ }^{33}\right)$. Antero de Quental parece já dominar com perícia esse fenómeno da fusão dialéctica de adesão emocional e estranhamento racional no panfleto Defesa da Carta Encíclica de Sua Santidade Pio IX contra a chamada opinião liberal-"escrito repassado",

(31) Antero de Quental, Cartas, vol. II, p. 919.

$\left.{ }^{32}\right)$ J. P. Oliveira Martins, "Prefácio" a Os Sonetos Completos de Antero de Quental, Porto, Livraria Portuense de Lopes \& C..2. Editores, 1886, p. 32.

$\left({ }^{33}\right)$ Numa carta a José da Cunha Sampaio: "O humorista é aquele homem alegre que cada vez que ri está por um triz a chorar." (cf. Cartas, vol. I, p. 50). 
como logo viu Oliveira Martins $\left({ }^{34}\right)$, "daquela ironia em que o paradoxo se confunde com a razão e o humor afecta ares de sinceridade", graças à "faculdade de desdobramento mental" que subjaz ao "objectivismo" do enunciado. Depois, plausivelmente favorecidas por tendências caracterologicas de Antero $\left({ }^{35}\right)$, as injunções e metamorfoses da ironia romântica - enquanto desenrolar schlegeliano de "auto-criações e autodestruições sucessivas" $\left.{ }^{36}\right)$, inconfundível com a mera "presunção da inteligência" e indiscernível da auto-ironia $\left({ }^{37}\right)$ - ganham alento na comparticipada criação heteronímica do primeiro Fradique Mendes $\left({ }^{38}\right)$. Mas ultrapassam, afinal, esse fenómeno histórico-cultural, desenvolvendo recorrentemente as aquisições, também com feições lúdicas e satânicas, resultantes em boa parte $\left({ }^{39}\right)$ do convívio e das relações paragramáticas com $\mathrm{H}$. Heine (magistralmente estudadas por Manuela Delille) $\left({ }^{40}\right)$ e paralelamente com Nerval, mas também com E.A. Poe e com um Baudelaire que, como detectou a proverbial clarividência de Costa Pimpão, influi sobre Antero no sentido da adopção de uma estratégia discursiva de desdobramento objectivante $\left({ }^{41}\right)$.

$\left({ }^{34}\right)$ No artigo "Antero de Quental", publicado em 1890 na lisboeta Revista Ilustrada (e citado por Bruno Carreiro, ob. cit., p. 234).

${ }^{(35}$ ) Veja-se José Alves, Antero de Quental - Les mortelles contradictions, Paris, Centro Cultural Português, 1982.

$\left.{ }^{(36}\right)$ Cf. Joaquium de Carvalho, "Evolução Espiritual de Antero", loc. cit., p. 645.

$\left({ }^{37}\right)$ Veja-se a carta a Oliveira Martins datada de 30 de Maio de 1987 (Cartas, vol. II, pp. 841-842).

${ }^{38}$ ) Veja-se Joel Serrão, O Primeiro Fradique Mendes, Lisboa, Livros Horizonte, 1985; e J. C. Seabra Pereira, recensão crítica a essa obra, in Colóquio/Letras, n. ${ }^{\circ} 100$, Nov.-Dez. 1987, pp. 170-173 (com reparos, justamente, à subestimação da continuidade da ironia romântica).

$\left({ }^{39}\right)$ Como denunciam cartas importantes de Antero, desde 1873 ("Lembra-se daquele dito de Heine, que um alemão, quando discute, só metade do seu espírito sustenta o que ele sustenta, enquanto a outra metade está com o adversário? Pois sucede-me coisa parecida. Desde que chego a definir a minha ideia, boa metade do meu espírito se vira logo contra ela", in Cartas, vol. II, pp. 226-227) até 1878 ("Tenho agora lido Heine, em alemão. Que poeta! É talvezo único que a gente ainda pode ler na idade madura dos 36 anos. Penso que é porque nos versos dele o antídoto anda sempre ao pé do veneno, quero dizer, ao pé da ilusão das paixões a ironia, a divina ironia salvadora", in Cartas, vol. II, p. 439).

$\left({ }^{40}\right)$ Cf. Maria Manuela G. Delille, A Recepção Literária de H. Heine no Romantismo Português, Lisboa, I.N.C.M., 1984, Cap. 2, pp. 161-255.

$\left({ }^{4}\right)$ Mas não "parnasiana", ao contrário do que pretendia o saudoso Mestre ("Antero de Quental e Baudelaire", in Gente Grada, Coimbra, Atlântida, 1952, pp. 51, 52, 56), pois a atracção pela "impassibilidade do artista perante os vários estados de consciência do seu tempo" nãosurge acompanhada por outros vectores importantes do Parnasianismo, e muito menos integrada na sua interacção sistémica. 


\section{Manifestação poética de estados de consciência heterónomos}

Consequentemente, ao apresentarem 1869, n'O Primeirode Janeiro, os "Poemas do Macadam" de Carlos Fradique Mendes, Antero de Quental dava a escola satânica por expressão literária da "consciência moderna", enquanto com o poema "A Carlos Baudelaire" exaltava o "sereno estilista" que, sob a aparência de impassibilidade, sabia como poucos "o que é a dor". Ao publicar n'A Folha, em 1873, o díptico de sonetos "O Possesso (Comentário às 'Litanies de Satan')" fá-lo acompanhar de uma nota $\left({ }^{42}\right)$ onde se afirma que o autor "não é por modo algum solidário com as desconsoladoras doutrinas que expõe nestes dois sonetos. Uma coisa é o homem e o pensador, outra o artista, para quem, dentro da verdade estética, todos os factos psicológicos têm valor igual, (...) quando trata de definir praticamente os vários modos de ser da alma humana". E ao publicar o soneto "O Convertido" n' $O$ Cenáculo, em 1875, Antero de Quental juntava-lhe nova e consonante nota: "O autor propôs-se, nestes versos, descrever um estado singular de espírito muito característico do nosso tempo, e não inculcar uma doutrina desoladora. Ninguém o pode tornar responsável por sentimentos que não são os seus, embora sejam muito reais, e com os quais é tão pouco solidário como o patologista com o estado mórbido que estuda e descreve".

Não pode esta atitude ser reduzida à dimensão da blague, nem ao alcance circunstancial, quando provém de um autor que ainda em 1890 e até em textos de reflexão filosólica, recorre a idêntica estratégica discursiva, em passos como o que as Tendências Gerais da Filosofia na segunda metade do século XIX consagram ao Espiritualismo da filosofia ecléctica francesa (de V. Cousin, Ravaisson, Maine de Biran, etc.). Aí, o sujeito da enunciação não se desdobra apenas entre compreensão histórica e distanciamento crítico, mas também entre

${ }^{(42}$ ) Também ela perpassada sem dúvida de ironia, mas de uma ironia talvez inextricável das resistências subliminares da formação cristã aos ímpetos iconoclastas e à vertigem sacrílega, e ainda indiscernível dos reflexos de cautela defensiva, com prevenções perante a instituição literária e contra previsíveis reacções de escândalo e condenação na sociedade portuguesa - como deixa entender a carta que, a esse propósito, escreve a João Penha: "e uma nota que não me parece escusada, atenta a parvoíce de muitos dos nossos contemporâneos, contemporâneos no tempoe em nada mais" (Cartas, vol. I, p. 186). 
reconhecida simpatia pelo alcance compensatório da doutrina perante os destroços anímicos provocados pelo Cientismo e um derradeiro esforço para não resvalar até à identificação com essa doutrina: por um lado, frontal denúncia do que há de "frágil mas elegante, de pouco peso mas de boa aparência e útil cómodo" nessa doutrina que "nunca chegou a ser uma filosofia"; e por outro lado, e a despeito de dissentir dos seus pressupostos, calorosa defesa da sua transitória, mas incontornável, bondade: "Não desdenhemos todavia desse espiritualismo. (...) Inspirou um grande e brilhante cicloliterário: amparou milhares de consciências vacilantes, num período de transição cheio de incerteza, de amargos pesares, de inquietas aspirações: criou uma escola de moralistas eloquentes: identificou-se com as causas mais nobres, pugnando pelo direito e pela liberdade dos povos: forneceu o pão do espírito, não só em França mas por toda a Europa latina, a duas gerações por certo não indignas da história" $\left({ }^{43}\right)$.

Ora, entendemos que idêntico procedimento - de reconhecimento de pertinência dialéctica, se não de necessidade histórica, no processo de evolução progressiva da Consciência humana, a atitudes de espírito não desposadas pela pessoa do autor, mas que assim mesmo fazem jus a seu momento de representação literária, a sua oportunidade de aceder ao estatuto de verdade estética - interfere e avulta na construção de obra poética da maturidade de Antero, nomeadamente em composições como o díptico de sonetos intitulado "Espiritualismo", mas também na constituição cíclica d'Os Sonetos Completos.

\section{As leituras tutelares da poesia de Antero e a constituição dramática d'Os Sonetos Completos}

Por 1942, opondo-se, na senda de Sant'Ana Dionísio $\left({ }^{44}\right)$, à difusão da leitura dos Sonetos de Antero como livro de memórias de um pensamento, Costa Pimpão mostra, a propósito de vários textos, que

$\left({ }^{43}\right)$ Antero de Quental, Obras Completas - Filosofia, Lisboa, Universidade dos Açores/Editorial Comunicação, 1991, p. 38.

$\left({ }^{44}\right)$ Sant'Ana Dionísio, Antero. Algumas notas sobre o seu drama e a sua cultura, Lisboa, 1934, p. 151 ss. 
com frequência "o Poeta continua a achar dignos de expressão poética ideias e sentimentos que a sua razão teria todo o direito de considerar anacrónicos", em particular sempre que tal resultasse da persistência do seu interesse "pelo conflito da consciência humana com o universo, do mundo físico com o mundo moral, da necessidade com a liberdade" ${ }^{45}$ ). Se por aí despontava a percepção de uma dramaticidade transcendental na lírica de Antero, o certo é que Costa Pimpão inflecte para a sobrevalorização de outro vector dramático, gradativamente reconduzido à expressão de vivências individuais: primeiro, entende que a "capacidade de visionário" leva Antero "a projectar, com frequência, para fora de si, os fantasmas do seu próprio pensamento, e a debater com eles os grandes problemas da existência. $O$ debate chega a tomar a forma de diálogo - num esforço supremo para objectivar o drama."; depois, considera que Antero exprime poeticamente "odrama da alma com os seus espectros, com as vozes obscuras da natureza, com o terrível Absoluto que o cinge, com o Mistério impalpável que o esmaga."; finalmente, sumariza que "o Livro dos Sonetos aparece-nos, do princípio ao tỉm, como uma interpretação estética dos instantes dramáticos de uma consciência" ${ }^{46}$ ). Assim se torna possível que a orientação positivista da história literária, e a preocupação de, em clave biografista, desautorizar as ordenações por ciclos dos Sonetos $\left({ }^{47}\right)$, instrumentalizem redutoramente em Costa Pimpão a perspicaz detecção do mais incomum vector dramático da lírica anteriana, de modo que a fenomenologia poética do espírito de uma época - com representação lírico-dramática de "os vários estados de consciência do seu tempo" $\left({ }^{48}\right)$ - se diluirá em favor da expressão das tensões íntimas duma subjectividade complexa.

$\left({ }^{45}\right)$ Álvaro Júlio da Costa Pimpão, "Antero - O Livro dos Sonetos" (Conferência de 1942), in Escritos diversos, Coimbra, Acta Universitatis Coimbrigensis, 1972, pp. 521-523.

$\left({ }^{46}\right)$ Idem, ibidem, pp. 532, 532 e 534.

$\left({ }^{47}\right)$ Cujas injunções eram já patentes no artigo de 1941 "Antero de Quental e Baudelaire", que lamentava: "a crítica confundiu o pensador com o artista, e, o que é mais notável, o próprio Poeta aceitou, de bom grado, essa confusão, visto que permitiu o ajustamento da autêntica cronologia dos seus Sonetos à ideia falsa de uma biografia espiritual mais verosímil" (Álvaro Júlio da Costa Pimpão, Gente Grada, p. 56).

$\left.{ }^{48}\right)$ Idem, ibidem, p. 51. 
Também António Sérgio, na sequência de trabalhos mais temporãos sobre Antero $\left({ }^{49}\right.$ ), se mostra, pelos alvores da década de 40 (com a edição da obra de Quental para a Livraria Couto Martins), muito sensível à dramaticidade da lírica anteriana, quer ao nível da encenação alegórica e dialógica da metanóia exemplar do poeta, quer ao nível da apresentação de opções ideológicas ou atitudes existenciais dotadas de alteridade e intersubjectivamente experimentadas. Em A. Sérgio, porem, a pretensa antinomia Antero nocturno versus Antero luminoso $\left({ }^{50}\right)$ (e sobretudo o colete de forças que, com cobertura ou não da tendência luminosa, isto e, da "aspiração racionalista do pensador", Sérgio cuida de aplicar à tendência nocturna, isto é, ao "fruto tóxico do temperamento mórbido do honeni") ${ }^{51}$ ) e o comentário profiláctico perante tudo o que - religioso ou afectivo - aparece a A. Sérgio como deletério, evasivo, alienante, limitam poderosamente a compreensão do rasgo objectivante da poesia de Antero e, inviabilizando em clave psicologista (e de pedagogia socio-ideológica) uma verdadeira crítica de identificação, desfiguram o recorte dramático de muitos dos textos poéticos anterianos.

Assim, a propósito do díptico "Espiritualismo" (e, correlatamente, dos sonetos "Oceano nox", "Contemplação" e do díptico "Redenção"), pondera António Sérgio que "nem sempre os sonetos anterianos significam opiniōes ou atitudes do autor, senão que consistem, algumas vezes, em sentidas representações de determinadas doutrinas, ocorrendo por isso concepções opostas, teses e antíteses" ( $\left.{ }^{52}\right)$. Já de si hipotecado a uma dialéctica serial que A. Sérgio institui por conta própria $\left({ }^{53}\right)$ no quadro de uma construção cíclica cuja unilateralidade logo se trai $\left({ }^{54}\right)$, este reconhecimento da heterodramatização, em que o poeta "visiona

(49) Notas sobre os Sonetos e as Tendências Gerais da Filosofia de Antero de Quental, Lisboa, Liv." Ferreira Editora, 1909, e "Os dois Anteros (O luminoso e o nocturno)", in Ensaios IV, Lisboa, Scara Nova, 1934.

$\left({ }^{50}\right)$ Cf. na reedição pela Livraria Sá da Costa Editora (Lisboa, 1962), passos da "Nota preliminar" e das introduções ou notas aos "ciclos" de sonetos nas pp. XVII-XVIII, XX-XXI, 11, 75-76, 77, 127-128, 139, 142, 155, 159, 160, 225.

(51) António Sérgio, "Nota preliminar do organizador da presente edição", in Antero de Quental, Sonetos, Lisboa, Sá da Costa, 1962, pp. XVII-XVIII.

${ }^{52}$ Idem, ibidem, p. 222 ss.

( ${ }^{53}$ ) Cf. ibidem, p. 193.

(54) Cf. ibidem, p. 194. 
poeticamente uma concepção filosófica, e não trata de enunciar uma doutrina sua" $\left({ }^{55}\right)$, atrofia-se nos restantes comentários aos Sonetos de Antero, mesmo quando a detecção da ironia (a propósito de "O Convertido") ou da martiniana "ironia transcendente" (a propósito de "Divina Comédia" e "Disputa em Família") ${ }^{56}$ ) deveria pelo contrário sustentá-lo. Pode A. Sérgio falar de teatralização de este ou aquele soneto (como quando vê n'"O Palácio da Ventura" "como que uma tragédia em quatro actos") $\left({ }^{57}\right)$; de facto, transitando por comentários como o que lhe suscita "O Convertido" - "observa-se o anseio da evasão para o divino: porém, conversão, para falar com verdade, não existe aí", "a uma psique, porém, é possível situar-se simultaneamente adentro e fora de determinada atitude, de determinado sentimento, de determinada crença, e tomar em fantasia uma situação mental sem aderir objectiva e intelectualmente a ela" $\left({ }^{58}\right)$-, o que António Sérgio tem em mente é uma "teatralidade psíquica" $\left({ }^{59}\right)$, observada sobretudo para vigiar as emergências "nocturnas", isto é, uma dramatização vista de uma perspectiva não anedoticamente biografista, mas psicologista. Assim, na introdução geral ao livro dos Sonetos abona-se em Faria e Maia e em certa carta de Antero de 1872 para preparar a leitura de um poeta eminentemente homo duplex, de si mesmo contraditório $\left({ }^{60}\right)$; na introdução aos sonetos que agrupa no "Primeiro Ciclo - Da expressão lírica do amor-paixão", desenvolve a visão da "realidade poética" como fantasmagoria "interna", aplicando-a às "poesias do autor dos Sonetos" ${ }^{61}$ ); nas anotações referentes ao díptico "Tese e Antítese"

("5) Idem, ibidem, p. 224.

${ }^{(56)}$ Cf. ibidem, pp. 134 e 183.

(57) Idem, ibidem. p. 99. Para os "poemas lúgubres", veja-se p. 255.

( ${ }^{(58)}$ Idem, ibidem, pp. 134 e 136.

${ }^{(59)}$ Idem, ibidem, p. 13.

${ }^{(60}$ Idem, ibidem, pp. XXI e XXV.

(61) Pelas latentes, mas depois coarctadas, inovações hermenêuticas que apesar do psicologismo encerra, merece ser transcrito este passo: "os sonetos de Antero são expressões emotivas, mas nem sempre confissões intelectuais do homem. De outra forma dito: nem sempre as poesias do autor dos Sonetos representam atitudes ou modos-de-ser-do-espírito a que Antero dá adesão intelectual e objectiva, istoé, que ele adopta e converte em opiniōes bem suas. Porém, não se julgue por aí que tais obras de arte, não enunciativas de opiniōes do poeta, hão-de ser por esse facto friamente didácticas, - histriónicas, manufacturadas, academicistas, vamos. Não: a atitude que exprinem é na verdade sentida, com cálido paralelismo de sentimento-ideia: mas não énecessário, para que tal aconteça, que a atitude sentida obtenha, ademais, $o$ assentimento 
reitera, oscilantemente, que nem sempre os versos de Antero exprimem "sentimentos ou modos de ver a que adere com consciente e completa adesão. Alguns, pelo contrário, tão só representam atitudes possíveis, concepções alheias, que eventualmente reproduz com simpatia artística" ${ }^{62}$; em contrapartida, a propósito do soneto "Transcendentalismo", lamenta que as duas quadras lhe dêem "um carácter tão patológico" e que "o afirmado culto do supra-sensível seja uma fuga do homem sofredor e enfermo, não uma especulativa conclusão do filosofo" ( ${ }^{63}$ ); finalmente, em derradeira nota de esclarecimento ao comentário ao soneto "Ad amicos", A. Sérgio considera que "não se pode converter a cronologia dos sonetos numa cronologia das crenças pessoais de Antero. Em qualquer fase da nossa vida nos é possível fantasiar uma atitude de espírito, e exprimi-la numa obra artística" $\left.{ }^{64}\right)$.

Entretanto, já pelo menos desde 1934, ao estudar as relações entre "Antero de Quental e a Filosofia de Eduardo de Hartmann" $\left({ }^{65}\right)$, Joaquim de Carvalho parece garantir a precedência (tanto em termos de anterioridade, quanto de aprofundamento) na compreensão do alcance do vector dramático na poesia de Antero. Admitindo sem dúvida o interesse de "assistir ao drama íntimo e solitário da luta de sentimentos opostos" $\left.{ }^{(66}\right)$, Joaquim de Carvalho defende então, a propósito de "Nirvana", "À Virgem Santíssima" e "O Convertido", e prevalecendo-se de testemunhos de Antero (cartas a Lobo de Moura, nota n'O Cencículo), que estamos aí perante uma "mesma atitude impessoal, descritiva da fenomenologia do coração humano", mediante a qual "o soneto exprime a atitude de quem evoca e descreve estados psicológicos de outrem". Essa intuição vem logo maculada pelo juízo de que se trata "portanto (de) uma concepção mais ou menos livresca" $\left({ }^{67}\right)$; e logo depois, ao mesmo tempo que reitera que cada um

intelectual do realizador do poema, - a aprovação do filósofo, a adesão da pessoa, "de verdade" e "a sério". É fantasiada com vida, com inteligência intuitiva, com simpatia perfeita: mas não é adoptada" (idem, ibidem, pp. 12-13).

$\left({ }^{62}\right)$ Idem, ibidem, p. 59.

$\left({ }^{63}\right)$ Idem, ibidem, p. 127.

(64) Idem, ibidem, p. 275.

${ }^{(65)}$ Texto primeiramente publicado no In Memoriam de Delfin Guimarães, Lisboa, 1934.

${ }^{(6)}$ Joaquim de Carvalho, Obra Completa, Lisboa, Fundação Calouste Gulbenkian, 1978, vol. I, p. 411.

$\left({ }^{67}\right)$ Idem, ibidem, p. 414. 


\section{Poesia, alta voz dramática}

daqueles sonetos "exprime uma concep̧̧ão autónoma e diversa da vida, sem que o Poeta tome partido por qualquer delas", numa atitude "espectacular, isto é, de observador do espírito humano", Joaquim de Carvalho valoriza que Antero o faça não com a indiferença do observador, mas "porque o comove a ânsia impotente do infinito e vive dramaticamente a carência duma resposta absolutista às dúvidas sobre a essência e o destino da vida". E, assim, também aqui a expressão dramática de um "estado de espírito" pessoal - o de "sensação da suspensão da consciência e da carência duma antropologia filosófica", que Joaquim de Carvalho crê sintetizado no soneto "Homo" de 1875 - sobreleva e dilui a dramatização apresentativa de estados de consciência heterónomos $\left({ }^{68}\right)$.

Noutro estudo posterior "Sobre a origem da concepção da inconsciência de Deus em Antero de Quental" $\left.{ }^{69}\right)$, confrontado com os dois factos irredutíveis que lhe parecem a impossível conciliação do "personalismo" de Antero com a concepção hartmanniana e, por outro lado, a adesão do soneto "Inconsciente" àquela concepção, Joaquim de Carvalho considera que Antero, ao topar com tal doutrina "e pela surpresa que the causou, pelo espanto que imaginou provocar (...) deu-lhe expressão poética, pois (...) só a forma literária e o contraste da ironia lhe pertencem" $\left({ }^{\circ}\right)$. Em contrapartida, na versão dilatada do estudo "Evolução espiritual de Antero" ( $\left.{ }^{71}\right)$, Joaquim de Carvalho coarcta a leitura da dramatização supra-egótica, latente ainda em vários passos do decisivo estudo - ao analisar os sonetos pessimistas dos ciclos quarto e quinto, Joaquim de Carvalho julga estar perante uma "subjectividade (...) que não é autobiografia" e sublinha que os versos de Antero "dão-nos, acima de tudo, uma concepção extraversa da realidade." $\left({ }^{2}\right)$ - e tende a refluir para os limites do drama psicológico, estabelecendo mais comummente, logo de início, que os poemas de Antero de Quental "especialmente os Sonetos, exprimem o

$\left({ }^{68}\right)$ Idem, ibidem, pp. 416-417.

${ }^{(69)}$ Inicialmente publicado na Biblos (Revista da Faculdade de Letras da Universidade de Coimbra), vol. XX, 1944.

$\left({ }^{70}\right)$ Joaquiun de Carvalho, Obra Completa, vol. II, (1981), pp. 113-114.

( $\left.{ }^{71}\right)$ A versão originária (Lisboa, Seara Nova, 1929) surgiu muito acrescentada e modificada nos Estudos sobre a Cultura Portuguesa do Século XIX. (Anteriana), Coimbra, Imprensa da Universidade, 1955.

$\left({ }^{2}\right)$ Joaquim de Carvalho, Obra Completa, vol. II, t. II, (1983), pp. 642 e 630. 
drama de uma consciência reflectida que busca ardentemente o sentido último da existência", particularizando depois "o diálogo" de dois homens expresso nos sonetos do ciclo de 1874-1880 (num clima de "inquietação e quase angústia de imaginação e sentimento"), etc $\left({ }^{73}\right)$.

Decididamente, tanto ou mais do que o devemos pensar para o próprio Antero, as leituras tutelares da sua poesia $\left({ }^{74}\right)$ não podiam privar-se da inteireza do sujeito (ainda que regianamente "ser conflituoso") eda sua soberania expressiva. Temiam-se de as hipotecar se ratificassem hermenêuticamente a constituição dramática d'Os Sonetos Completos em nome da representação, não só das tensões da consciência agónica individual, mas também das tensões do Mundo natural concebido como grande teatro do "psicodinamismo" e das tensões da História humana concebida como dialéctica de consciências do mundo transindividuais.

10. A poesia do "lugar onde de determinadas combinações de ideias e sentimentos"

No entanto, desde que Antero, sem suspeitar da premonição metafórica, decide ir "enterrar-se na poltrona do filósofo" $\left({ }^{5}\right)$, a dramatização objectivante, heteronomizante, da sua poesia ver-se-ia mais exigida para sondar e propor as componentes que se iam confrontando na evolução do seu pensamento, e cada vez mais vertendo em diaporemática a dialéctica do dinamismo ascensional da História e do Homem, que - em dissenção com os transformismos, com as filosofias "naturalistas" (deterministas, mecanicistas) da Natureza, com o monismo de Haeckel - surge comandada teleonomicamente pela plenitude da consciência moral, pela "santidade".

Pensador e poeta da ironia transcendental, Antero será cada vez mais pensador de uma consciência que, sendo actividade intelectual e actividade volitiva à maneira de Schopenhauer e de Hartmann $\left({ }^{76}\right)$, faz

\footnotetext{
$\left({ }^{73}\right)$ Idem, ibidem, pp. 546 e 626.

$\left({ }^{74}\right)$ Veja-se ainda António Salgado Júnior, ob. cit., p. 47.

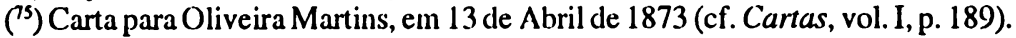
p. 387.

$\left({ }^{76}\right)$ Cf. Fernando Catroga, "A ideia de evolução em Antero de Quental", loc. cit.,
} 


\section{Poesia, alta voz dramática}

coincidir o regime da metafísica indutiva com o de uma ascensão mística (em termos laicos e imanentistas) de modo a realizar a dialéctica ascendente do eu pessoal até ao "eu impessoal, absoluto, todo razão e vontade" $\left({ }^{77}\right)$. E a metafísica indutiva de Antero implica um regime mental de dramatização objectivante $\left({ }^{8}\right)$ - da mesma dramatização que parece adequada à representação dos embates do Homem com o pessimismo transitivo na conquista do optimismo transcendental $\left({ }^{79}\right)$, à representação de uma visão do Mundo segundo uma "interpretação vitalista do idealismo alemão" (com o Espírito Absoluto hegeliano a ser revisto em termos de pampsiquismo hartmanniano) $\left({ }^{80}\right)$, à representação da História segundouma fusão teleológica da matriz hegeliana e dos desígnios proudhonianos com novas aportações acomodadas à dialéctica serial $\left({ }^{81}\right)$, enfim à representação do processo da subjectividade humana interpretado segundo o mesmo evolucionismo dialéctico e teleológico ${ }^{82}$ ).

A experiência poética e o texto literário, que correspondem - umas vezes antecipando, outras vezes ecoando - a esse desenvolvimento diaporemático, exigiam decerto a Antero o primeiro nível dramático: o lirismo tensional ou agónico das "memórias de uma consciência", para respeitar, aliás, não só os dissídios entre pensamento e pendores afectivo-volitivos, ou as alterações de pensamento e sentimento perante uma mesma realidade (veja-se, por exemplo, os dois sonetos "A um crucifixo"), mas para respeitar também as oscilações da inteligência entre tendências diversas de imanentismo ou entre tipos diferentes de pessimismo (como destacou Óscar Lopes) $\left({ }^{83}\right)$ e até para objectivar textos poéticos cuja execução lhe agrada, embora não saiba o que querem dizer (como confessa a Lobo de Moura em 1887 sobre o

$\left({ }^{77}\right)$ Assim se exprime Antero de Quental na parte final das Tendências Gerais de Filosofia na Segunda Metade do Século XIX (cf. Obras Completas-Filosofia, p. 161).

$\left({ }^{78}\right)$ Cf. Fernando Catroga, "A metafísica indutiva de Antero de Quental", Biblos, vol. LXV, 1985, pp. 506-507.

$\left({ }^{79}\right)$ Cf. Fernando Catroga, "O optimismo transcendental (em Antero de Quental)", in Antero de Quental, 1842-1891, Lisboa, Biblioteca Nacional, 1991, pp. 86 e 92.

$\left.{ }^{80}\right)$ Cf. idem, ibidem, pp. 86-87, e idem, "A ideia de evolução em Antero de Quental", loc. cit., p. 365. -388 .

$\left({ }^{81}\right)$ Idem, "A ideia de evolução em Antero de Quental", loc. cit., pp. 371, 372, 387 -

$\left.{ }^{(82}\right)$ Idem, ibidem, pp. 376-377 e 380.

$\left({ }^{83}\right)$ Óscar Lopes, "O Antinaturalismo de Antero", loc. cit., pp. 32 e 34. 
soneto "Mors-Amor") ( $\left.{ }^{84}\right)$. Exigiam também, tanto n'Os Sonetos Completos como nos poemas lúgubres "Os Cativos", "Os Vencidos" e "Entre Sombras", o segundo nível dramático do lirismo dialógico e alegorizante, prosopopeico ou não, em que o sujeito lírico endossa a enunciação a outras entidades (Natureza, Morte, etc.). Exigiam, então, uma outra dimensão dramática, romanticamente conatural à pragmática e à retórica desses dois níveis, e que vem a ser a da teatralidade da voz, apostrofante e cenográfica. Mas acolhiam também o imperativo desse outro nível de dramatização da lírica que Joaquim de Carvalho, Costa Pimpãoe António Sérgio entreviram e abandonaram, talvez justamente pela dificuldade com que acompanhariam em Antero os momentos e os movimentos que relevam de uma deslocação do conceito de sinceridade poética (afinal em congruência com a doutrina estética emergente já na retirada "Nota" às Odes Modernas!) e que são também os momentos e os movimentos que relevam de uma deriva da subjectividade desde a primorromântica problemática fichteana do $\mathrm{Eu}$ Absoluto e dos eus individuais até à problemática tardorromântica que mitigadamente nos permite aproximar Antero de Kierkegaard...

Por isso, a palavra de ordem de Antero - sobre a sua poesia, sobre a poesia de outrem, sobre a Poesia enquanto Arte - passa a ser: dramatizar! dramatizar! A carta de 1881 em que agradece e elogia o poema Sacerdos Magnos de António Feijó constitui um ponto culminante dessa directriz: "Só desejara que toda aquela nobre poesia tivesse sido vazada num molde dramático, que lhe desse acção, vida e verdadeiro relevo. Tenho hoje para mim ser esta a condição suprema da Arte. A forma analítica parece-me convir só ao lirismo, que retrata momentos psicológicos, ou muito apaixonados ou muito íntimos, mas sempre elementares. Mas, fora desta esfera restrita, a poesia, tornada mais complexa, parece-me que requer uma forma sintética, a acção objectiva, o drama (dando à palavra a sua acepção mais geral), poderosa pela sua mesma impessoalidade" $\left({ }^{85}\right)$.

(84) Antero de Quental, Cartas, vol. I, p. 378.

${ }^{85}$ Idem, ibidem, p. 567. Por conseguinte, Antero acrescentava que "as melhores ideias, apenas desenvolvidas, pendem para o didáctico - género inferior - e muitos elementos, verdadeiramente poéticos, deixam de atingir, por falta de acção, aquele poder de comoçãoque virtualmente encerram"; e exemplificava com as Odes Modernas: 
Por isso, no Outono de 1885 , procurava orientar a leitura d'Os Sonetos Completos por Oliveira Martins neste sentido: "Quanto aos Sonetos, a perfeição seria que V. discreteasse e filosofasse sobre alguma ou algumas das questões psicológicas, morais e outras, que o livro sugere, sem dizer nada do Autor, sujeito pessoalmente insignificante, e apenas o lugar onde de determinadas combinações de ideias e sentimentos.(...)E, apesar da obra ser tão individual, visto que é lírica, afinal o que ali interessa é só o que tem de geral e humano" $\left.{ }^{86}\right)$. Assim, a lírica dramatizada era suposta ter ido ao encontro da manifestação poética daquele "fundo mais íntimo" do eu pensante "que já não é eu mas o espírito humano", conforme discorria Antero em 1873 para o mesmo Oliveira Martins $\left({ }^{87}\right)$. Assim, a lírica dramatizada pudera ir manifestando, em contiguidades por vezes complementares $\left({ }^{88}\right)$, por vezes antitéticas, "alguns aspectos mais frisantes" da diaporemática humana, conforme o próprio Antero explicava, também em 1873, a Lobo de Moura (pronunciando-se sobre "Inania regna" e "Eutanásia", adentro da série "Elogio da Morte") $\left({ }^{89}\right)$.

\section{Uma consequente interaç̧ão hermenêutica com a dramaticidade da poesia anteriana}

É tempo, pois, de inserirmos entre os vectores da nossa releitura da poesia de Antero de Quental a tão indiciante oscilação dessa mesma poesia, e das suas exegeses mais ou menos paradigmáticas, entre as tensões da agónica consciência individual e as tensões pampsíquicas do Mundo ou as tensões, na História, de formas transindividuais de consciência da Vida, ou seja, entre o dramatismo dos conflitos intras-

\footnotetext{
"entre outros defeitos, têm esse capital. Estou convencido de que metade apenas, ou a ainda a terça parte das ideias realmente poéticas, que pus naquele livro, teriaun bastado, se não estivessem simplesmente analisadas e desenvolvidas, mas dramatizadas e vivas, para uma obra vinte vezes superior".

${ }^{(86)}$ Idem, ibidem, vol. II, p. 756.

${ }^{87}$ Idem, ibidem, vol. I, p. 226.

${ }^{88}$ Veja-se, por exemplo, e curiosamente passando pela fase transitória de construção da 2. "edição das Odes Modernas comoum "livro novo" (cf. Bruno Carreiro, ob. cit., vol. II, p. 43), o que ocorreu com o díptico "A um Crucifixo" (Cartas, vol. I, pp. 257-258).
}

$\left({ }^{84}\right)$ Cf. Cartas, vol. I, p. 213. 
subjectivos e a dramaticidade dos confrontos de consciências do Mundo intersubjectivas, heterónomas (como a do "monge da Idade Média" por quem "foi composto" o soneto "À Virgem Santíssima" ou a do "filósofo alemão" que constitui o mais "crível (...) autor" do soneto "Nirvana") $\left({ }^{90}\right)$.

Tal (dis)posição de leitura - que umas vezes lhe permitirá continuar a incidir no corpo de cada soneto, mas outras vezes exigir-lhe-á que actue no âmbito das correlações entre dois ou vários sonetos - deve coabitar decerto, num renovado horizonte de expectativas, com outra atitude crítica (de que não há que retirar forçosamente inferências negativas no plano da axiologia estética). Trata-se do já referido reconhecimento dos limites da modernidade artística de Antero, que aquele drama consciencial e aquela dramatização literária recobrem, semoseliminar-nodesencontro, porventura involuntárioe desgostante, de Antero com as novas faces da civilização urbano-industrial e no seu alheamento do litígio entre a modernidade científico-sociológica e a modernidade artística pós-romântica.

Por um lado, Cesário só veio acentuar contrastivamente a exígua penetração da Cidade moderna na poesia de Antero, e quanto denuncia essa resistência. Para além da amarga evidência -e assim mesmo como espaço ideológico, mais da ordem do simbólico e do lado da negatividade - que a cidade ganha no rebate de "Justitia mater" ("Mas nas negras cidades, onde solta/Se ergue de sangue madida a revolta, /...// Há mais alta missão, mais alta glória:/ O combater, à grande luz da história, / Os combates eternos da justiça!") $\left.{ }^{(91}\right)$, pouco mais fica... E esse pouco, por entre estereótipos emblemáticos de equi vocado baudelairianismo à maneira de Guilherme de Azevedo, ainda surge à contraluz do investimento visionário, prospectivo, numa Cidade outra, "Assente sobre a rocha de Igualdade" (em que desemboca "À História") $\left({ }^{92}\right)$ e à contraluz do investimento nostálgico numa outra semântica de "cidade", que noutros poemas designa os Campos Elíseos dos deuses exilados ou "a cidade ideal da Natureza!" $\left({ }^{93}\right)$.

\section{$\left({ }^{90}\right)$ Cf. Cartas, vol. I, pp. 161 e 162.}

(') Antero de Quental, Odes Modernas, ed. cit., p. 107, e Os Sonetos Completos, ed. cit., p. 68. Cf. também à 19." oitava de "À História", in Odes Modernas, p. 19.

(92) Antero de Quental, Odes Modernas, ed. cit., p. 30.

${ }^{93}$ ) Veja-se "Saudades pagãs", in Primaveras Românticas, 3." ed., Coimbra, Imprensa da Universidade, 1926, pp. 178-179. 
Por outro lado, ainda não cuidosa de consubstancializar o seu pathos de especulação e intervenção na forma "como integridade dinâmica e concreta que tem nela própria o seu conteúdo" $\left({ }^{94}\right)$, a pośtica de Antero oculta o irresolvido problema da dicotomia fundo vs. forma, bem como a insegurança no equacionar de ideação e de Gemüt (em Antero "Sentimento", "coração", "Sonho"...); e a sua poesia, embora menos caudalosa quando cingida pelo soneto, não tolera tornar-se menos ressonante, mantendo-se imune ao vírus da depuração malferida que, desde Poe e Baudelaire, estigmatiza a modernidade estética.

Romanticamente sensível, et pour cause, à temática hegeliana (mas oriunda de Vico) do anúncio da morte da Arte às mãos dos sucessos da racionalidade científica e praxeológica e do progresso técnico-sociológico, próprios da modernidade matricial, Antero inclina-se por vezes para a tese daquela morte anunciada da Arte (nomeadamente em "O futuro da Música") $\left({ }^{95}\right)$ ou para a tese afim da caducidade histórica da Poesia (nomeadamente em "A poesia na actualidade", de 1881, e em carta-prefácio de 1889 à Lira Romântica de Molarinho) $\left.{ }^{96}\right)$. Mas continuará a contrariar tais teses, mais decididamente na prática poética do que na reflexão teórica, prevalecendo-se das assimetrias no processo de actualização universal daquela modernidade científico-sociológica e constituindo o seu discurso poético em paladino e arauto dos necessários êxitos cognitivos e das consequentes reivindicações emancipalistas.

Por isso mesmo, todavia, Antero nem pode abdicar da busca de novas modalidades formais para a sua poesia lírica $\left({ }^{97}\right)$, nem pode chegar a identificar essa sua arte lírica com a outra modernidade-a modernidade estética que começava a cumprir-se pelo cal vário da autoquestionação, da auto-anacronização, da autodesconstrução superadora.

$\left({ }^{94}\right)$ Como mais tarde diria, com outros formalistas russos, Boris Ejchenbaum (cf. Théorie de la littérature. Textes des formalistes russes (...), Paris, Scuil, 1966, p. 44).

${ }^{(95}$ ) Cf. Antero de Quental, Prosas da Época de Coimbra, ed. cit., p. 262 ss., e Joel Serrão, "Antero: a ruptura com o passado c a inquietação metafísica - Nos primórdios da filosofia anteriana", in Diário de Notícias, 5 de Julho de 1987, Suplemento "Cultura", pp. IV-V.

${ }^{\left({ }^{6}\right)}$ Cf. Antero de Quental, Prosas, vol. II, Coimbra, Inprensa da Universidade, 1926, pp. 310-326, e Cartas, vol.II, pp. 952-954. Cf. também Joel Serrão, "Na pista dos motivos da destruição das "Poesias lúgubres", in Antero de Quental, Hino da Manhã e outras poesias do mesmo ciclo, Lisboa, Livros Horizonte, 1898, pp. 13-25.

$\left({ }^{97}\right)$ Cf. o estudo derradeiramente citado de Joel Serrão, pp. 24-25. 
Em compensação, se a (poli)dramaticidade da poesia lírica de Antero assim arrasta consigo e disfarça um lastro de indisponibilidade missional para o melindre e a suspeita da modernidade estética, o vector mais profundo de dramatização da lírica em Antero compromete-se já com esta modernidade pelo pacto que estabelece entre procedimento profético e desdobramento irónico (e, logo, consciência do jogo literário) $\left({ }^{98}\right)$, bem como pela reformulação anti-expressivista a que sujeita o conceito de sinceridade artística.

Entendida nesse sentido, tal dramatização da lírica, num Antero que (como assinalou Oliveira Martins) é já poeta que "Pensa o que sente; Sente o que pensa" $\left({ }^{99}\right)$, coenvolve um vector de modernidade que so a historicidade poss-pessoana da nossa interaç̧ão hermenêutica com a sua poesia está em condições de actualizar $\left({ }^{100}\right)$.

$\left.{ }^{(98}\right)$ Pois, na tradição da ironia romântica, "A distanciação do autor em relação à obra, a dramatização do enunciador no enunciado, desvenda a consciência dojogo, mas tal consciência é já a razão de ser e o próprio fazer da literatura" (Maria de Lurdes Ferraz, ob. cit., p. 42).

$\left({ }^{99}\right)$ J. P. Oliveira Martins, "Prefácio" a Os Sonetos Completos de Antero de Quental, Porto, Livraria Portuense de Lopes \& C." Editores, 1886, p. 8.

$\left({ }^{100}\right)$ E que do mesmo passo nos permite percepcionar o processo e as virtualidades da construção macrotextual do livro d'Os Sonetos Completos: veja-se J. C. Seabra Pereira, "Para um retorno à 'íntima unidade' d'Os Sonetos Completos de Antero", in Máthesis (Universidade Católica Portuguesa-Centro Regional de Viseu), n. 22, 1992. 